\title{
BIOLOGICAL AND HISTOLOGICAL EFFECTS OF METARHIZIUM ANISOPLIAE ON THE COTTON LEAFWORM, SPODOPTERA LITTORALIS (BOISD.) (LEPIDOPTERA: NOCTUIDAE)
}

\section{LOTFY, DALIA E. ${ }^{1}$, MARWA M. M. EL SABAGH ${ }^{1}$, YASMEIN E. AHMED ${ }^{1}$ and HEBA YOUSEF ${ }^{1,2}$}

1. Plant Protection Research Institute, ARC, Dokki, Giza, Egypt.

2. Chemistry Department, Faculty of Science and Arts, University of Jeddah, Khulais, Jeddah, Saudi Arabia.

(Manuscript received 4 October 2015)

\begin{abstract}
$\mathrm{T}$ oxicological, biological and histological effects of the isolated entomopathogenic fungus Metarhizium anisopliae from the red palm weevil adult on the newly molted $2^{\text {nd }}$ and $4^{\text {th }}$ instar larvae of the Egyptian cotton leaf worm, Spodoptera littoralis (Boisd.), were investigated under laboratory conditions at $270 \pm 2^{\circ}$ and $60 \% \pm 5 \%$ R.H. Results revealed a decrease in the mean larval, pupal, and adult durations for the $2^{\text {nd }}$ and $4^{\text {th }}$ instar larvae surviving treatment with the $\mathrm{LC}_{50}$ of $2.8 \times 10^{8}$ and $2.8 \times 10^{9}$ spore/ml for the two tested instar larvae, respectively. Treatment also caused a reduction in the pupation and adult emergence percentage. There was also a great reduction in the mean number of eggs/female and the mean number of hatched eggs; The histological changes in the mid gut tissues in $6^{\text {th }}$ instar surviving treatment with $\mathrm{LC}_{50}$ of $M$. anisopliae as newly ecdysed $3^{\text {rd }}$ instar larvae was investigated. Sections in mid gut of untreated $S$. littoralis showed linning with columnar cells surrounded by cross longitudinal muscles fiber, the epithelial cells linning mid gut with its brush border and goblet cells. While, in mid gut of treated $S$. littoralis some epithelial cells which linning mid gut have lost their brush border, others were completely destructed.

Key words:

Spodoptera littoralis, Entomopathogenic fungi, Metarhizium anisopliae, Toxicology, Biology and Histology
\end{abstract}

\section{INTRODUCTION}

The Egyptian cotton leafworm, S. littoralis is an important pest in Egypt and other countries in Africa and Asia causing extensive economic losses in many cultivated crops (Frank et al., 1990). The extensive use of insecticides for controlling S. littoralis caused harmful effects on humans, living organisms and environment (Chaudhuri et al., 1999). The problems and hazards that have arisen as a result of using conventional insecticides were insentives for the search of alternative insecticides. Among these are microbial control agents which include bacteria, fungi, viruses, nematodes and protozoa (Dent, 2000). Metarhizium anisopliae (Metschnikoff) Sorokin is considered the most common entomopathogenic fungal species used as 
biological control agents against insect pests (Barra et al., 2013). It is widely dispersed in nature and commonly isolated from infected insect or soil (Razinger et al., 2014).

The present study aimed to study toxicity of $M$. anisopliae as a new isolate as well as biological and histological effects of $S$. littoralis mid gut post treatment with M. anisopliae.

\section{MATERIALS AND METHODS}

\section{Rearing of S. littoralis:}

S. littoralis were provided by the Department of the Cotton Leafworm, Plant Protection Research Institute, Dokki-Giza. Newly hatched larvae were transferred to clean glass jars covered with muslin held in position with rubber bands and incubated under laboratory condition at $27^{\circ} \pm 2{ }^{\circ} \mathrm{C}, 60 \pm 5 \% \mathrm{RH}$, and 8:16 LD photoperiod. They were fed on castor leaves and examined daily. Upon pupation, pupae were collected; sexed and emerged moths were placed in pairs in glass jars supplied with leaves on Tafla, Nerium oleander (L.) as an oviposition site.

\section{Isolated M. anisopliae:}

The fungus used was isolated from adult of the red palm weevil, Rhynchophorus ferrugineus Oliv., in Insect Pathogen Production Unit, Plant Protection Research Institute and grown on a Sabouraud dextrose yeast agar (SDYA) culturing medium. The fungus was identified according to Barent and Hunter (1977).

Spores of isolated fungus cultured on Sabouraud dextrose yeast agar (SDYA) medium were harvested under sterile conditions using sterile distilled water containing $0.02 \%$ Tween- $80^{\circledR}$.

The number of spores were counted using Neubaur Hemocytometer to determine the concentration of spores $/ \mathrm{ml}$. Six concentrations were prepared from the stock suspension by serial dilution to be used in bioassay. They were $2.8 \times 10^{6}, 2.8 \times 10^{7}$, $2.8 \times 10^{8}, 2.8 \times 10^{9}, 2.8 \times 10^{10}$ and $2.8 \times 10^{11}$ spores $/ \mathrm{ml}$.

Two sets of five replicates were prepared each contains 10 newly molted $2^{\text {nd }}$ and $4^{\text {th }}$ instar larvae. The larvae were introduced into a cheese cloth and dipped into the prepared suspensions. The same numbers of larvae were considered as a control in which larvae were dipped in sterile distilled water containing $0.02 \%$ Tween- $80^{\circledR}$. All larvae were fed on clean and fresh castor oil leaves. 
Mortality was recorded daily and accumulative larval mortality was determined at the end of the larval stage. The mortality percentages were corrected according to Abbott's formula (Abbott, 1925).

Toxicity was presented graphically as log/probit regression lines, $\mathrm{LC}_{25}, \mathrm{LC}_{50}, \mathrm{LC}_{75}$ and LC $_{90}$ were estimated according to (Finney, 1971) using "LdPLine ${ }^{\circledR "}$ software.

\section{Biological studies:}

The $2^{\text {nd }}$ and $4^{\text {th }}$ larvae instar were collected and treated with $L_{50}$ value of $M$. anisopliae and the following biological parameters were studied: larval and pupal duration of each instar, and percentage of pupation. Pupae were sexed and then placed in pairs in the glass globes. Subsequently, the following was determined: percentage of adult emergence, longevity of moths and the fecundity and fertility of eggs/female. A control was set comprising a similar number of untreated moths.

\section{Histopathological studies:}

Samples of healthy and infected larvae (Third-instar larvae of $S$. littoralis infected with $\mathrm{LC}_{50}$ value of $\mathrm{M}$. anisopliae) were fixed in $10 \%$ neutral formalin; the samples were dehydrated in graded ethanol to xylene and embedded in paraffin.

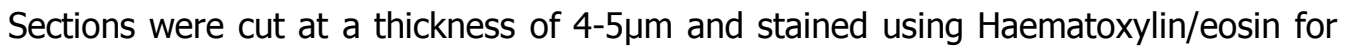
larval tissue according to (Bancroft and Stevens, 1996). The stained sections were observed and photographed using an optical microscope.

\section{RESULTS AND DISCUSSION}

\section{Bioassay:}

As shown in (Table. 1 and Fig. 1) the efficacy of M. anisopliae conidia on the $2^{\text {nd }}$ and $4^{\text {th }}$ instar larvae of $S$. littoralis was expressed in terms of $L_{25}, L_{50}, L_{75}$ and $\mathrm{LC}_{90}$. It was found that this isolate is pathogenic to the two tested instar larvae. The probit analysis indicated that $\mathrm{LC}_{25}, \mathrm{LC}_{50}, \mathrm{LC}_{75}$ and $\mathrm{LC}_{90}$ values of $2^{\text {nd }}$ and $4^{\text {th }}$ instar larvae after $48 \mathrm{hr}$. of treatment were $2.8 \times 10^{6}$ and $2.8 \times 10^{7}, 2.8 \times 10^{8}$ and $2.8 \times 10^{9}, 2.8 \times 10^{10}$ and $2.8 \times 10^{11}$ and $2.8 \times 10^{12}$ and $2.8 \times 10^{12}$ spores $/ \mathrm{ml}$. respectively,. These results agree with those of Loc et al. (2010) who studied the effect of $B$. bassiana and M. anisopliae on Black citrus aphids and Citrus pyrilla. In addition, when De Senna-Nunes et al. (2002) evaluated the effects of two isolates of $A$. flavus and two isolates of Penicillium corylophilum on adults of Musca domestica, they found that one of the A. flavus isolates killed $100 \%$ of flies three days after treatment, while the two P. corylophilum isolates killed $100 \%$ of flies on the $7^{\text {th }}$ day after treatment. 
M. anisopliae is one of several natural agents for controlling a broad range of insects by direct penetration of the host cuticle. (Tin et al., 2008). There is an increasing interest in the use of entomopathogenic fungi for the biocontrol of insect pests (Evans, 1999).

The significance of the present study is to illustrate the ability of the tested entomopathogenic fungal isolate; $M$. anisopliae to show positive influences on larval mortality as well as induced malformation in treated $2^{\text {nd }}$ and $4^{\text {th }}$ instar larvae of $S$. littoralis. Spores were used in different concentrations to estimate efficiency of the fungal isolate as a biological control against $2^{\text {nd }}$ and $4^{\text {th }}$ instar larvae of $S$. littoralis under laboratory conditions.

Table 1 . Susceptibility of S. littoralis 2 nd and 4th instars larvae to $M$. anisopliae

\begin{tabular}{|c|c|c|c|c|c|}
\hline Instars & $\mathrm{LC}_{25}$ & $\mathrm{LC}_{50}$ & $\mathrm{LC}_{75}$ & $\mathrm{LC}_{90}$ & Slope \\
& $($ Spores $/ \mathrm{ml})$ & $($ Spores/ml) & $($ Spores $/ \mathrm{ml})$ & $($ Spores $/ \mathrm{ml})$ & \\
\hline $2^{\text {nd }}$ instars & $2.8 \times 10^{6}$ & $2.8 \times 10^{8}$ & $2.8 \times 10^{10}$ & $2.8 \times 10^{12}$ & 0.3283 \\
\hline $4^{\text {th }}$ instars & $2.8 \times 10^{7}$ & $2.8 \times 10^{9}$ & $2.8 \times 10^{11}$ & $2.8 \times 10^{12}$ & 0.3189 \\
\hline
\end{tabular}

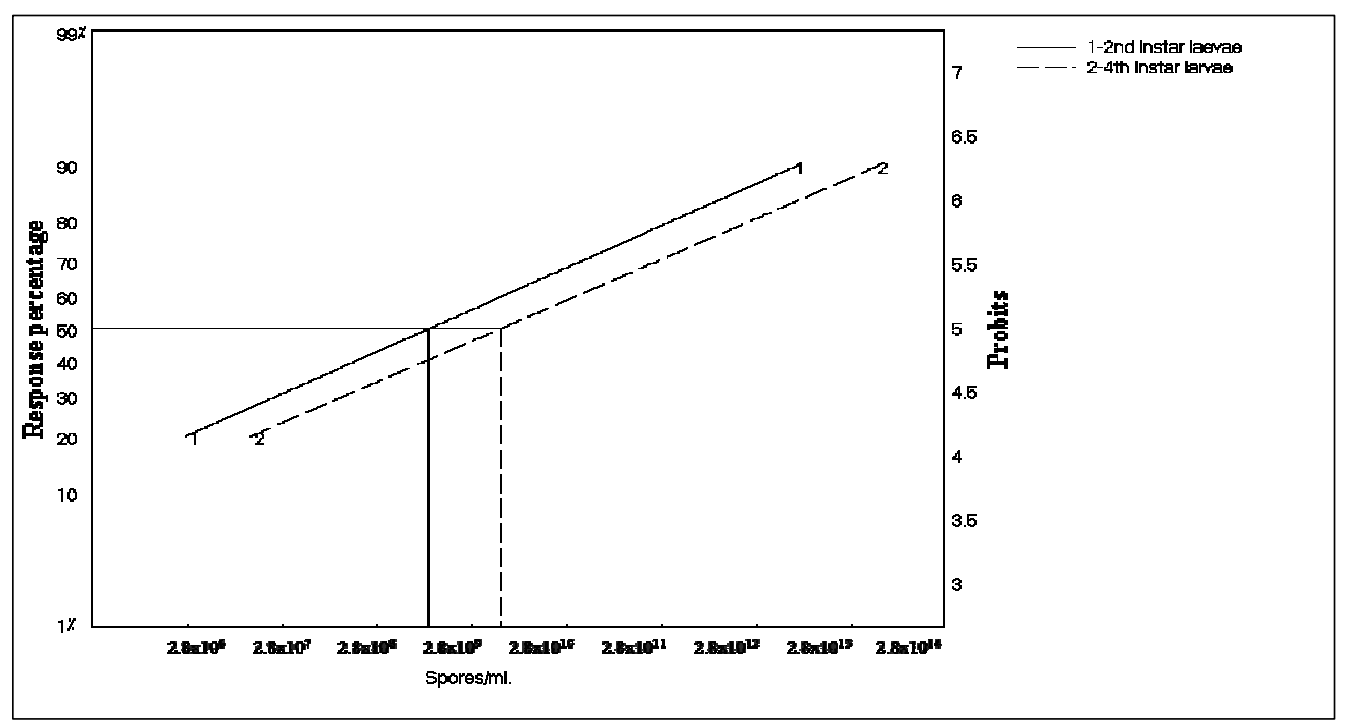

Fig. 1. Concentration log probit toxicity lines of $M$. anisopliae against $2^{\text {nd }}$ and $4^{\text {nd }}$ S.littoralis. 


\section{Effect on biological aspects:}

The results in Table (2) summarized the duration of larvae treated as $2^{\text {nd }}$ instars lasted 12 days up to pupation which was less than the control by nearly four days. Meanwhile, pupal stage durated 12.3 days as compared to 13 days in the control, i.e. nearly a day less. Treatment of $4^{\text {th }}$ instars larvae with $\mathrm{LC}_{50}$ of $M$. anisopliae also increased the remaining larval instars duration to 11 days as compared to 12 days in the control. Meanwhile, pupal duration was 11.3 days as compared to 13 days in the control, These differences were found to be statistically significant.

The percentage of larvae entering pupation was markedly less in treated $2^{\text {nd }}$ and $4^{\text {th }}$ instars larvae which were 49.2 and $50 \%$, respectively, less than the control. Meanwhile, percentage of adult emergence was slightly decreased than the control to 92 and $95 \%$ for the respective mentioned treated instars. Moth's emerging from treated $2^{\text {nd }}$ or $4^{\text {th }}$ instar larvae with $L_{50}$ of $M$. anisopliae showed a shorter life span than the untreated insects.

Table (3) shows that the mean number of eggs laid for both females emerged from treated $S$. littoralis $2^{\text {nd }}$ and $4^{\text {th }}$ instar larvae was decreased significantly, compared with their counterpart of the untreated ones. This was also clear in the mean number of hatched eggs compared to the controls. The number of eggs laid was recorded in the mating treated moths resulted from treated $2^{\text {nd }}$ and $4^{\text {th }}$ instar larvae giving a mean of 847 and 671 eggs, respectively. The number of hatched eggs was recorded for the mating combination of treated moths resulted from treated $2^{\text {nd }}$ instar larvae giving a mean of 528 hatched eggs while those from treated $4^{\text {th }}$ instar larvae gave a mean of 622 hatched eggs compared to the normal moths that gave a mean number of 2103 hatched when resulted from treated $2^{\text {nd }}$ instar larvae and 1827 hatched eggs for the $4^{\text {th }}$ instar. These differences were found to be statistically very highly significant.

These results agreed with those of Hafez et al. (1997) who treated Phthorimaea operculella larvae with Beauveria bassiana; and Noma and Strickler (2000) who investigated the effects of $B$. bassiana infection on ovipositional behavior of Lygus hesperus. In addition, when Dubois et al. (2004) investigated the effect of two commercial preparations of $B$. bassiana and $B$. brongniartii, they found a reduction in adult longevity of the beetle Anoplophora glabripennis. Also, the obtained results agreed with those of Abd El-Kareem (2007) who treated larvae of Ostrinia nubilalis with $A$. flavus. 
Table 2. Effect of $\mathrm{LC}_{50}$ of $M$. anisopliae on the mean larval duration, pupation percentage, mean pupal duration, adult emergence and mean adult longevity of $S$. littoralis treated as $2^{\text {nd }}$ and $4^{\text {th }}$ instars larvae.

\begin{tabular}{|c|c|c|c|c|c|c|}
\hline Treated & Mean larval & Pupatio & Mean pupal & Adult & \multicolumn{2}{|c|}{$\begin{array}{c}\text { Mean adult longevity } \\
\text { (days } \pm \text { S.E.) }\end{array}$} \\
\hline Instars & (days \pm S.E.) & $\%$ & (days \pm S.E.) & $\%$ & 우 & $\hat{\sigma}$ \\
\hline $2^{\text {nd }}$ instars & $12.5 \pm 0.28 * *$ & 49.2 & $12 \pm 0.1^{*}$ & 92 & $11.3 \pm 0.30 *$ & $12.33 \pm 0.14 * *$ \\
\hline Control & $16 \pm 0.28$ & 100 & $13 \pm 0.5$ & 100 & $12.67 \pm 0.38$ & $14.33 \pm 0.11$ \\
\hline $4^{\text {th }}$ instars & $11 \pm 0.3^{*}$ & 50 & $11.3 \pm 0.1^{*}$ & 95 & $11.33 \pm 0.1 * *$ & $13.67 \pm 0.28^{* *}$ \\
\hline Control & $12 \pm 0.1$ & 100 & $13 \pm 0.1$ & 100 & $12.33 \pm 0.1$ & $15 \pm 0.38$ \\
\hline
\end{tabular}

*: Significant at $\mathrm{P}<0.05 \quad * *$ : highly significant a $\mathrm{P}<0.01$

Table 3. Effect of LC50 of $\mathrm{M}$. anisopliae on reproductive potential of $\mathrm{S}$. littoralis treated as 2 nd and 4th instars larvae.

\begin{tabular}{|c|c|c|c|c|}
\hline \multirow{2}{*}{$\begin{array}{c}\text { Mating } \\
\text { Combination }\end{array}$} & \multicolumn{2}{|c|}{$\begin{array}{c}\text { No. of eggs/\% } \\
\text { mean } \pm \text { S.E. }\end{array}$} & \multicolumn{2}{c|}{$\begin{array}{c}\text { No. of hatched eggs } \\
\text { (Mean } \pm \text { S.E.) }\end{array}$} \\
\cline { 2 - 5 } & $2^{\text {nd }}$ & $4^{\text {th }}$ & $2^{\text {nd }}$ & $4^{\text {th }}$ \\
\hline Treated & $847 \pm 16.8^{* * *}$ & $671 \pm 18.4^{* * *}$ & $528 \pm 8.5^{* * *}$ & $622 \pm 4.04^{* * *}$ \\
\hline Control & $2135 \pm 60.6$ & $1875 \pm 15.1$ & $2103 \pm 4.04$ & $1827 \pm 12.11$ \\
\hline
\end{tabular}

***: Very highly significant a $\mathrm{P}<0.001$.

\section{Histopathological effects:}

The histological structure of mid gut in larvae of Lepidoptera is well documented (Chapman, 1988). As seen in Fig. (2), the mid gut is lined with an epithelial layer, which rests on a basement membrane, and is composed of a single layer of three types of cells. (i) A majority of columnar cells containing a large coarse nucleus which occupies a middle position within the cell and bears a striated or brushlike border (microvilli). (ii) Goblet cells; which are somewhat calyx-shaped and are seen between the columnar cells; each of these cells has a large ampulla opening by a narrow neck through a small aperture on the inner surface. (iii) Regenerative cells are small in size and rest on the basement membrane between the bases of the other cells, and are round or elongated and contains a large nucleus surrounded by a small amount of strongly basophilic cytoplasm.

Within the midgut lumen, there is a thin peritrophic membrane, that surrounds the food mass. A musculosa surrounds the epithelial layer, composed of an 
inner circular layer and an outer layer of longitudinal muscle. As seen as in Fig. (3) The histological structure of the midgut of treated larvae many histological change than that the control. The peritrophic membrane was not closely lying to epithelial cells and the space in between the epithelium and peritrophic membrane was filled with few cytoplasmic vesicles. The obtained results agreed with those of QuesadaMorga et al. (2006) who found that crude soluble protein extracted from M. anisopliae elicited many histological changes to the midgut of $2^{\text {nd }}$ instar $S$. littoralis larvae: the midgut epithelium showed deterioration, there was destruction of the microvilli of the columnar cells, and formation of vacuoles. The histopathological changes induced by M. anisopliae treatment was more or less similar to histological changes detected by Thorvilson et al. (1985) and Srisukchayakul et al. (2005). Lysis of the cuticlar layer occurred before hyphae penetrated and invaded the epidermis. In addition, the epithelial cells of the midgut were highly affected because of fungal infection.

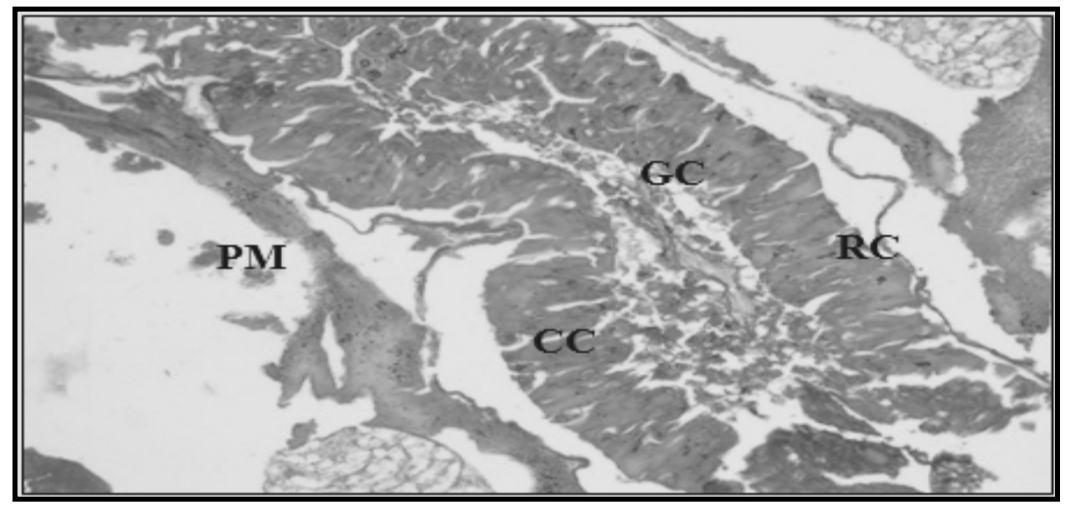

Fig. 2. Midgut of $S$. littoralis showing normal structure of:

PM : Peritrophic membrane, CC : Columnar cells, GC : Goblet cells, RC : Regenerative cells.

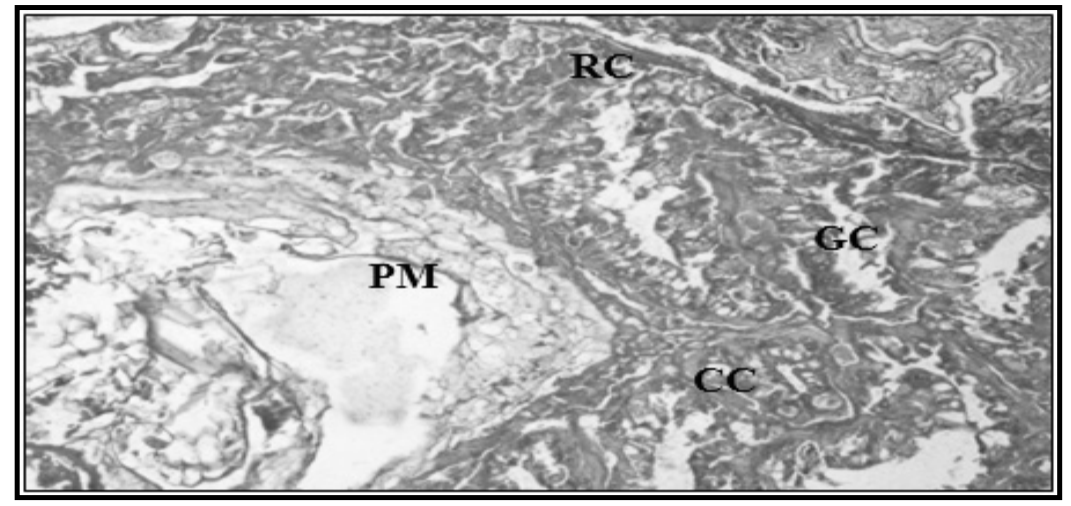

Fig. 3. Severe proliferation of some columnar cells as well as goblet cells other cells were necrosed.

PM : Peritrophic membrane, CC : Columnar cells, GC : Goblet cells, RC : Regenerative cells. 


\section{REFERENCES}

1. Abbott, W.S. 1925. A method for computing the effectiveness of an insecticide. J. Econ. Entomol. 18: 265- 277

2. Abd El-Kareem, S. M. 2007. Biological and histopathological studies on the effect of certain entomopathogenic microorganisms on the European corn borer, Ostrinia nubilalis Hübner (Lepidoptera: Pyralidae) M. Sc.Thesis, Fac. Sci., Ain Shams Univ. 187:140-143pp.

3. Bancroft, J.D. and A. Stevens. 1996. Theory and Practice of Histological Techniques $4^{\text {th }}$ edn, Churchill livingstone, New York.

4. Barra, P., L. Rosso, A.Nesci, and M. Etcheverry. 2013. Isolation and identification of entomopathogenic fungi and their evaluation against Tribolium confusum, Sitophilus zeamais, and Rhyzopertha dominica in stored maize.J.Pest Sci.,86:217226.

5. Barent, H. L. and B. Hunter. 1977. Illustrated Genera of Imperefect Fungi. Burgess Publishing Company, Minnesota, 2412 pp.

6. Chapman, R. F. 1988. The Insects Structure and Function. $3^{\text {rd }}$ edition. English Language Book Society/ Edward Arnold. 50-52 pp.

7. Chaudhuri, K.; S. Selvaraj and K. Pal. 1999. Studies on the genotoxicity of endosulfan in bacterial systems. Mutat. Res. 439: 63-67.

8. De Senna-Nunes, M.; G. Da Costa; V. Bittencourt; and J. Souza. 2002. Avaliaçăo in vitro dos fungos Aspergillus flavus e Penicillium corylophilum em adultos de Musca domestica (Diptera: Muscidae) Parasitol. Latinoam, 57: 9-14.

9. Dent, D. (2000). Biological Control. In: Insect Pest Management. $2^{\text {nd }}$ edition. London. CABI publishing. Ch. 6: 180-234 pp.

10. Dubois, T.; Z. Li; H. Jiafu and A. Hajek. 2004. Efficacy of fiber bands impregnated with Beauveria brongniartii cultures against the Asian long horned beetle, Anoplophora glabripennis (Coleoptera: Cerambycidae). Biolo. Control, 31: 320328

11. Evans, H. C. 1999. Biological Control of Weed and Insect Pests using Fungal Pathogens with Particular Reference to. Biocntrol News and Information. 20 (2), $63 N-68 N$.

12. Finney, D. J. 1971. Probit Analysis, A statistical Treatment of the Sigmoid Responsecurve $7^{\text {th }}$ Ed., Cambridge Univ. Press, Cambridge, England.

13. Frank, R.; H. E. Braun; B. D. Ripley and B. S. Clegy. 1990. Contamination of rural ponds with pesticides, 1971-1985. Ontario, Canada Bull. Environ. Contamin. Toxicol. 13: 771-817. 
14. Hafez, M.; F. Zaki; A. Moursy; and M. Sabbour. 1997. Biological effects of the entomopathogenic fungus, Beauveria bassiana on the potato tuber moth, Phthorimaea operculella (Seller). Pest Sci, 70(8): 158-159

15. Loc,N. T.; V.T. B. Chi, N. T. Nhan and T. T. B. Hong. 2010. Exploitation of Beauveria bassiana and Metarhizium anisopliae as potential biocontrol agents in integrated pest management (IPM) on citrus, Omonrice 17: 152-163.

16. Noma, T. and K. Strickler. 2000. Effects of Beauveria bassiana on Lygus hesperus (Hemiptera: Miridae) feeding and oviposition. Environ. Entomol.; 29 (2): 394-402

17. Quesada, M. E.; A. D. Carrasco and C. A. Santiago. 2006. Insecticidal and antifeedant activities of protein secreted by entomopathogenic fungi against Spodoptera littoralis (Lepidoptera: Noctuidae). J. Appl. Entomol. 130 (8): 452442

18. Razinger, J.; M. Lutz; H. J. Schroers; M. Palmisano; C. Wohler; G. Urek and J. Grunder. 2014. Direct plantlet inoculation with soil or insect-associated fungi may control cabbage root fly maggots. J. Invertebr. Pathol., 120:59-66.

19. Srisukchayakul, P.; C. Wiwat; and S. Pantuwatana. 2005. Studies on the pathogenesis of the local isolates of Nomuraea rileyi against Spodoptera litura. ScienceAsia, 31: 273-276

20. Thorvilson, H. G.; L. C. Lewis; and L. P. Pedigo. 1985. Histopathology of Nomuraea rileyi in Plathypena scabra larvae. J. Invert. Pathol.; 45(1): 34-40

21. Tin, M. S.; N. O. Weine; K. T. Moe and H. Thazin. 2008. Biocontrol potential of entomopathogenic fungus, M.anisopliae against Spodoptera litura. GMSAN International Conference on Sustainable Development:Issues and Prospects for the GMS. 
Metarhizium anisopliae التأثيرات البيولوجية والهيستولوجية لفطر على دودة ورق القطن الكبرى

داليا السيد محمد لطفي' ، مروة محمد محمود الصباغ'، ياسمين السيد احمد'، هبة يوسف 'r

$$
\text { r ا ـ . معهم بحوث وقابة النباتات - مركز البحوث الزراعية- دقي- جيزة- القاهرة }
$$

تمت دراسة النأثثر السمي و البيولوجي و الهيستولوجي للفطر الممرض للحشرات

Metarhizium anisopliae العمريين الثاني و الر ابع لدودة ورق القطن الكبرى تحت الظروف المعطية على درجة حرارة

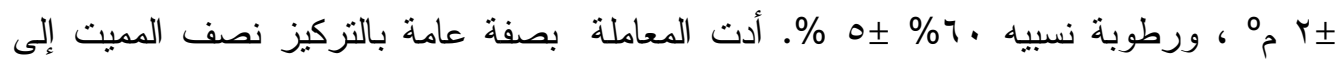
خفض في متوسط العمر اليرقي و العذري و انخفاض في نسبه التعذير ونسبه خروج الفراشات مقارنه

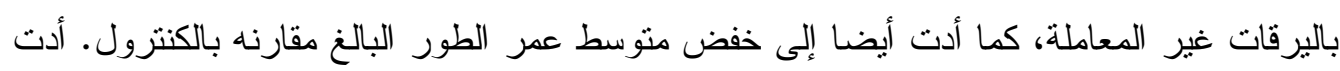

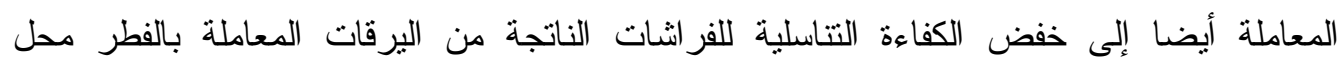
الدراسة حيث ظهر ذلك في انخفاض متوسط عدد البيض ومتوسط الفقس الناتج مقارنة بالكنترول. وتم عمل قطاعات في المعي الاوسط حيث وجد تدمير كامل وخلل في جميع انسجه وخلايا المعي

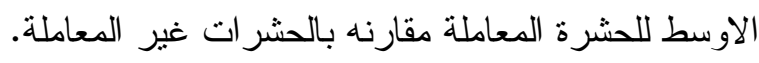

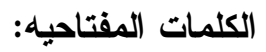
دودة ورق القطن، الفطر الممرض للحشرات Metarhizium anisopliae ، الهيسنوباثولوجي. 